\title{
Modelling sediment supply and transport in the River Lugg: strategies for controlling sediment loads
}

Conference or Workshop Item

Published Version

Whitehead, P. G., Lazar, A. N., Futter, M., Pope, L., Wade, A. J., Willows, R. and Burgess, C. (2010) Modelling sediment supply and transport in the River Lugg: strategies for controlling sediment loads. In: British Hydrological Society Third International Symposium: Role of Hydrology in Managing Consequences of a Changing Global Environment, 19-23 July 2010, Newcastle University, Newcastle upon Tyne, United Kingdom, pp. 1-6. Available at http://centaur.reading.ac.uk/16299/

It is advisable to refer to the publisher's version if you intend to cite from the work. See Guidance on citing. 
All outputs in CentAUR are protected by Intellectual Property Rights law, including copyright law. Copyright and IPR is retained by the creators or other copyright holders. Terms and conditions for use of this material are defined in the End User Agreement.

\section{www.reading.ac.uk/centaur}

\section{CentAUR}

Central Archive at the University of Reading

Reading's research outputs online 


\title{
Modelling sediment supply and transport in the River Lugg: strategies for controlling sediment loads
}

\author{
Paul Whitehead ${ }^{2}$, Attila Lazar ${ }^{1}$, Martyn Futter ${ }^{3}$, Linda Pope ${ }^{4}$, Andrew Wade ${ }^{1}$, \\ Robert Willows ${ }^{4}$ and Chris Burgess ${ }^{4}$
}

\author{
${ }^{I}$ School of Human and Environmental Sciences, University of Reading, UK; ${ }^{2}$ School of Geography and the Environment, University of Oxford, UK, \\ ${ }^{3}$ Swedish University of Agricultural Sciences, Uppsala, Sweden; ${ }^{4}$ Environment Agency, Thames Region, UK \\ Email:paul.whitehead@ouce.ox.ac.uk
}

\begin{abstract}
The River Lugg has particular problems with high sediment loads that have resulted in detrimental impacts on ecology and fisheries. A new dynamic, process-based model of hydrology and sediments (INCA- SED) has been developed and applied to the River Lugg system using an extensive data set from 1995-2008. The model simulates sediment sources and sinks throughout the catchment and gives a good representation of the sediment response at 22 reaches along the River Lugg. A key question considered in using the model is the management of sediment sources so that concentrations and bed loads can be reduced in the river system. Altogether, five sediment management scenarios were selected for testing on the River Lugg, including land use change, contour tillage, hedging and buffer strips. Running the model with parameters altered to simulate these five scenarios produced some interesting results. All scenarios achieved some reduction in sediment levels, with the $40 \%$ land use change achieving the best result with a $19 \%$ reduction. The other scenarios also achieved significant reductions of between $7 \%$ and $9 \%$. Buffer strips produce the best result at close to $9 \%$. The results suggest that if hedge introduction, contour tillage and buffer strips were all applied, sediment reductions would total $24 \%$, considerably improving the current sediment situation. We present a novel cost-effectiveness analysis of our results where we use percentage of land removed from production as our cost function. Given the minimal loss of land associated with contour tillage, hedges and buffer strips, we suggest that these management practices are the most cost-effective combination to reduce sediment loads.
\end{abstract}

\section{Introduction}

Sediment storage and transport in catchments is of economic and ecological importance. Soil loss from land surfaces is detrimental to agriculture and can lead to problems in surface waters through within-channel accumulation (Neal et al., 2006; Bilotta and Brazier, 2008; Scheurer et al., 2009). This can lead to problems for navigation, increased costs of water treatment, loss of salmonid spawning habitat and reduced light penetration in the water column. The EU Water Framework Directive (Council of the European Union, 2000) legally forces the EU Member States to maintain and improve the ecological status in the water bodies by preparing and implementing River Basin Management Plans. In addition, some chemicals, such as phosphorus, bind to sediment and the fate of these chemicals is intertwined with that of the sediment.

The deleterious effects of suspended sediment on aquatic biota are well known (Bilotta and Brazier 2008). These include direct mortality from gill clogging; impaired reproductive success from clogged spawning habitat or smothering juvenile organisms; altered blood physiology and impaired feeding success (Armstrong et al., 2003; Bilotta and Brazier, 2008, Greig et al., 2005). Land management and climate change may exacerbate these effects, especially if more intense rainfall or changing land management lead to increased erosion (Scheurer et al., 2009). Habitat requirements of Atlantic salmon (Salmo salar) have been described by Armstrong et al. (2003). Atlantic salmon typically require well-oxygenated gravel beds for spawning. Better links are needed between hydrology and ecology, specifically between landscapes and riverscapes. Tetzlaff et al. (2007) state that ecology, hydrology, land and rivers are considered in isolation far too often. Here we show how the INCA modelling framework (Whitehead et al., 1998, 2009; Wade et al,. 2002a, b, 2007) and specifically INCASed, can be used to link the terrestrial and aquatic components of catchments in terms of sediment generation and transport. A full description of the model is presented by Lazar et al. (2010). The INCA-Sed model has been applied to the Herefordshire Lugg River System to assess sediment controls on habitat and ecological functioning. The Herefordshire Lugg was chosen because of the present concern regarding the health of the salmonid fishery and other contemporary studies that have addressed the water quality issues of sediment and eutrophication (Walling et al., 2008; Wade et al., 2007).

\section{The INCA-Sediment model}

A prototype of the INCA-Sed model was produced by Jarritt and Lawrence (2007). Though named INCA-Sed, the original model (Jarritt, 2004; Jarritt and Lawrence, 2007) did not conform to the INCA framework. The underlying software used a series of finite difference equations operating on a fixed time step (15-minute time intervals). The version of the model described here has been implemented as a series of first-order differential equations. Terrestrial-phase equations 


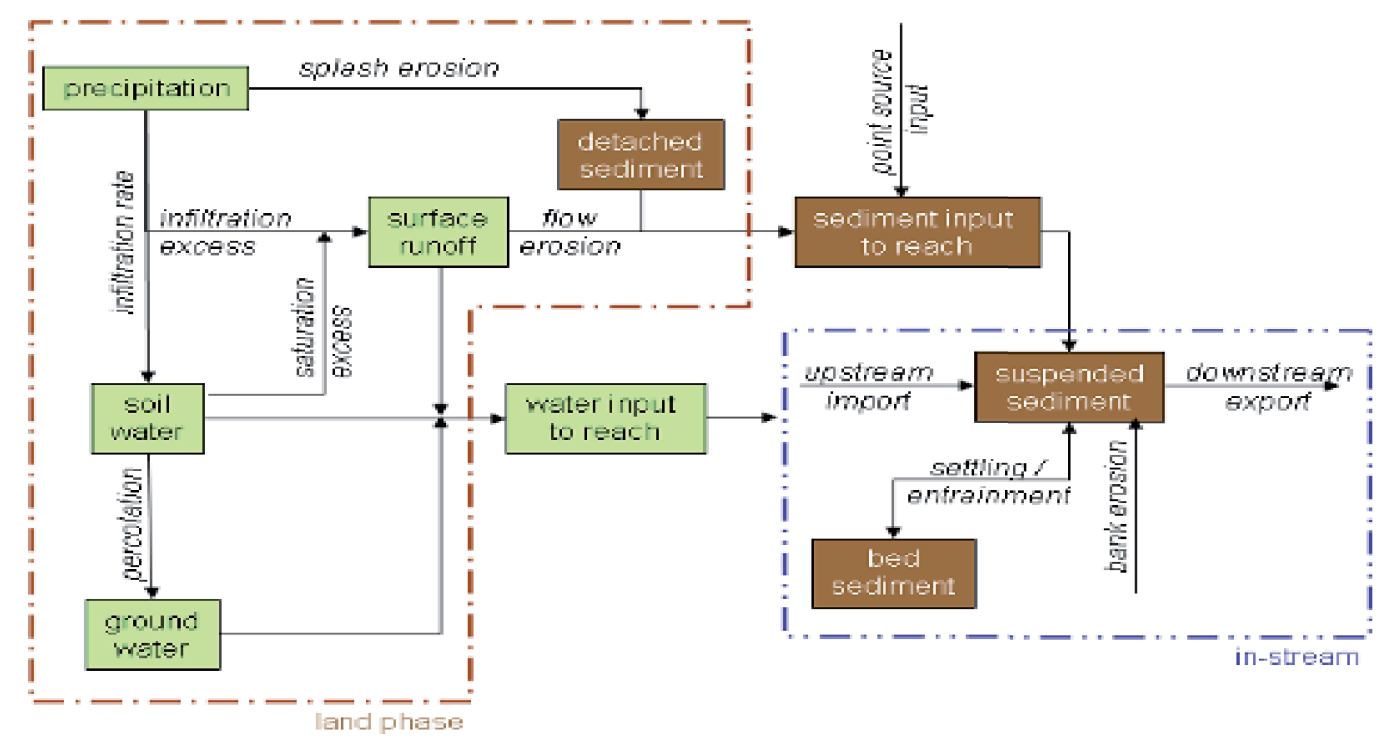

Figure 1 INCA-Sed Model Conceptual Structure (from Lazar et al. 2010)

are solved using a fourth-order Runge Kutta code. In-stream equations are solved using a Backwards Differentiation Formula Ordinary Differential Equation solver with Newton iteration from the CVODE library (Cohen and Hindmarsh, 1996).

The model (Lazar et al., 2010) has two main parts: (i) the land-phase delivery model which simulates the hydraulic and sediment generation and transport processes on the land, and (ii) the in-stream compartment that simulates processes and storage within the river segments. The conceptual model that forms the basis of the numerical and computational INCA-Sed is presented on Figure 1. In order to run the model, the following time series are necessary: rainfall, hydrological effective rainfall, soil moisture deficit and air temperature data series. It also requires information on the main land use and soil types in the study area, and soil characteristics such as grain size distribution.

\section{The RiverLugg system}

River Lugg is an important tributary of the River Wye in the western UK (Figure 2). It has been described in detail by Wade et al. (2007) and Jarvie et al. (2005). The River Lugg has a catchment area of $1077 \mathrm{~km}^{2}$ and is characterised by both upland and lowland areas. The long term mean annual precipitation is $1041 \mathrm{~mm}$ (Byton), $926 \mathrm{~mm}$ (Butts Bridge) and $847 \mathrm{~mm}$ (Lugwardine) in the upper, middle and lower reaches, respectively. Silurian sandstones underlie catchment headwaters, whereas the geology of the lower areas comprises mainly Old Red Sandstone. The latter moderates the high flow peaks considerably, giving a base flow index of 0.66 , which indicates the dominance of groundwater. Grassland and woodland with sheep and cattle production are the dominant land uses in the upper regions whereas arable lands with cattle production dominate in the lower reaches. Although many point pollution sources are located in the catchment, the most important point pollution source is the Leominster
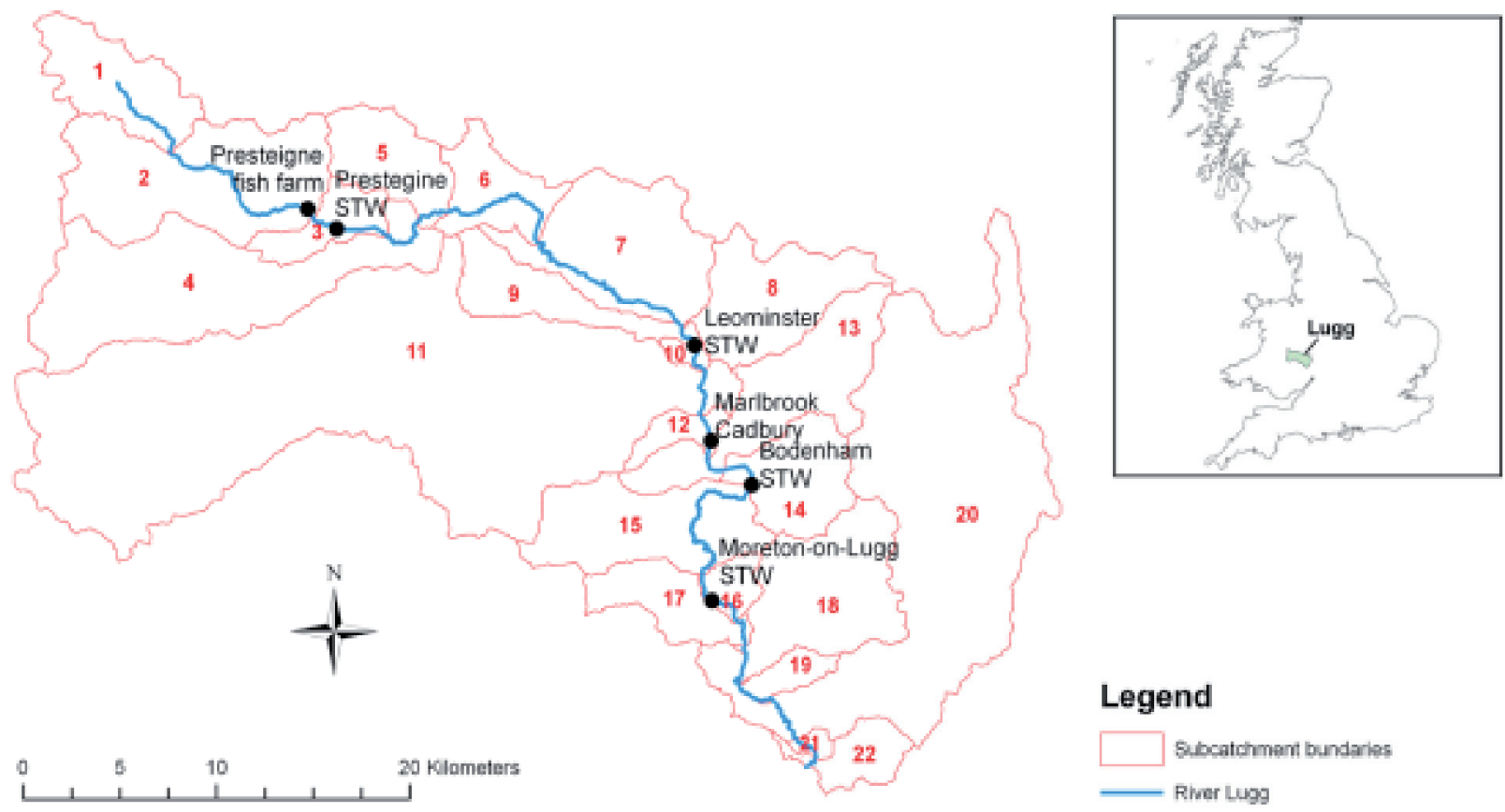

\section{Legend}

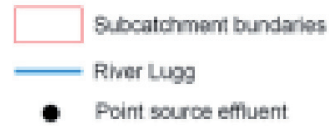

Figure 2 River Lugg catchment, sub-catchments and INCA Reach Structure 
STW, with a population equivalent (PE) of 10854. Other point sources along the main channel have much lower PE values: Moreton-on-lugg STW (2721 PE), Presteigne STW (1851 PE), Bodenham STW (600 PE), Mordiford STW (134 PE), Llangunllo STW (120 PE) (EA, unpublished).

The River Basin Management Plan for the Severn River Basin District (EA, 2009) lists 73 water bodies within the Wye catchment. The lower section of River Lugg (from the confluence of River Arrow to the confluence of River Wye) and two of its tributaries (Bodenham Brook, Moreton Brook) are also designated as riverine Special Areas of Conservation (SAC) because of their rich wildlife and habitat, including the nationally recognised salmon and brown trout fishery. Therefore, the water quality of the River Lugg is important to maintain the good ecological status of SACs of the Wye catchment. The same consultation document classified the River Lugg based on ecological status. The main tributary consists of four water bodies, three out of four having moderate ecological status. In these three, the fish population cause concerns about achieving good ecological status, whereas in the fourth water body, which has poor ecological status, the concern is with phytobenthos. In the lower section of the River Lugg (one of the SACs), two insecticides (cypermethrin and diazinon) are also listed in addition to the problematic fish population that all prevent the achievement of good ecological status. Additionally, the River Wye Salmon Action Plan (EA. 2003) states that diffuse sediment and nutrient pollution severely affects water quality.

\section{Model application to the River Lugg}

The modelling of the River Lugg catchment used the same 22 sub-catchments defined by Wade et al. (2007) when they modelled in-stream total and soluble reactive phosphorus concentrations in the catchment. Sub-catchment boundaries were delineated based on the location of water quality monitoring and flow gauging stations, and the location of sewage treatment works (STWs). Daily discharge time series for the simulation periods were obtained from the National Water Archive at Centre for Ecology and Hydrology, Wallingford. Weekly sediment concentrations measured in the River Lugg were provided by the Environment Agency (EA). Air temperature and precipitation data were obtained from the British Atmospheric Data Centre (UK Met OfficeMidas database). Soil types in the sub-catchments and their physical properties were obtained from the map annex (scale
1:250 000, Jarvis et al., 1984). Thirty different soil types were identified in the catchment and the HOST (Hydrology of soil types) classification system (Boorman et al., 1995) was used to group the soil types according to their hydrological properties. These HOST soil types were combined with the European CORINE Land Cover 2000 spatial dataset (European Environment Agency) to define the main landscape units and their proportions in each sub-catchment. Landscape units in INCA-Sed are indicative of erosion risk based on farming practice and soil type. The point source effluent loads discharging directly to the River Lugg were estimated from the EA effluent database, and include: a fish farm and STW at Presteigne, Leominster STW, Cadburys factory at Marlbrook, Bodenham STW and Moreton-On-Lugg STW. Since these STW effluent observations were monthly, gaps between observations were filled with the last observed value before the gap. The modelled period was 1995-2000 and a second period of 2003-2008.

Setting the model up is quite a complex process as the model simulates the sources of sediments in the catchment, transport of sediments into the river system and sediment movement down the river. The model also takes into account the hydrology and the varying deposition and resuspension processes occurring in the river. These vary according to water flow and velocity. A full description of the model application is given by Lazar et al. (2010). Figures 3 and 4show some results of the model output for daily flows and sediment concentrations for the period 1995-2000. An excellent fit to the observed data is obtained, suggesting the model is adequately simulating the river system. The model application was tested in a validation period over 2003-2008 to demonstrate the applicability of the model. Again, a good fit to the observed data was obtained for flow and sediments. The model can be used for a whole range of investigations and Figure 5 illustrates one interesting aspect of the model, where a profile of the flow, bed sediments and suspended sediments are given for a low flow condition in September 2005. The model suggests that at reach 11 there is a significant inflow of sediments into the river and being deposited on the bed of the river. This location corresponds to a large sub-catchment area of arable and grassland that joins the main river. This location is also just downstream of an urban area at Leominster. Another set of applications are now considered to evaluate the management options for controlling sediments in the Lugg.

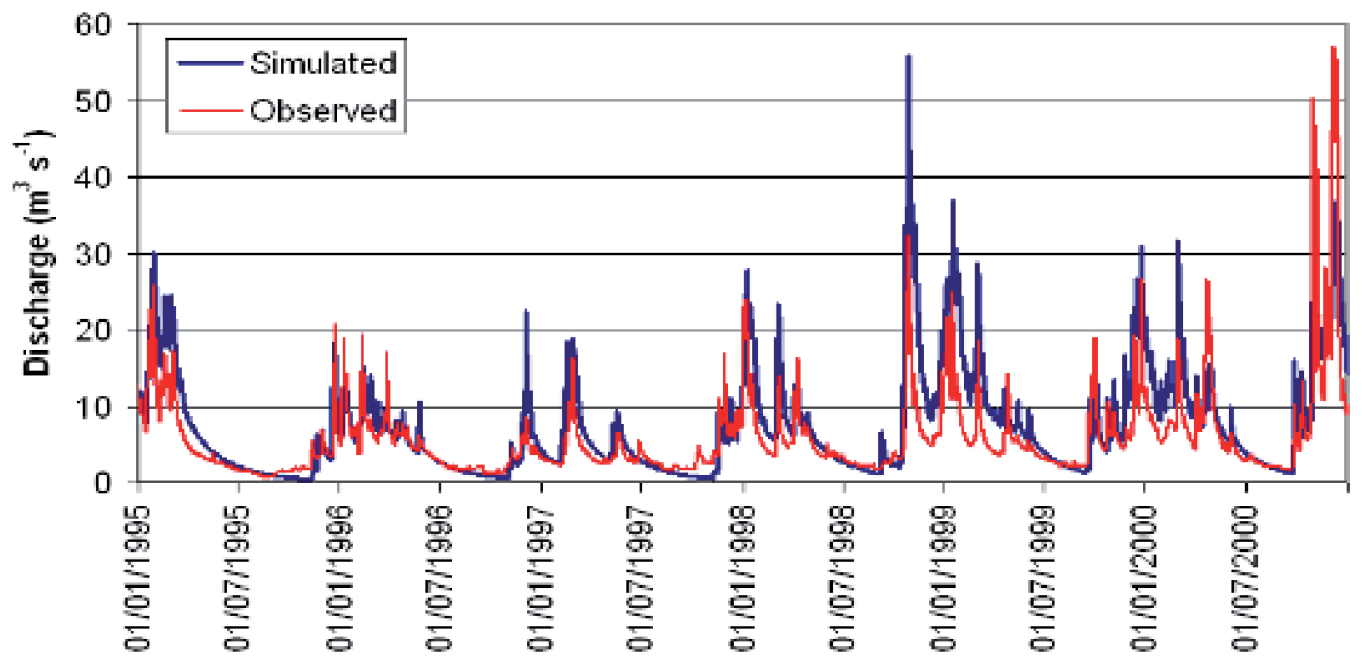

Figure 3 Observed and simulated flow for Reach 8 

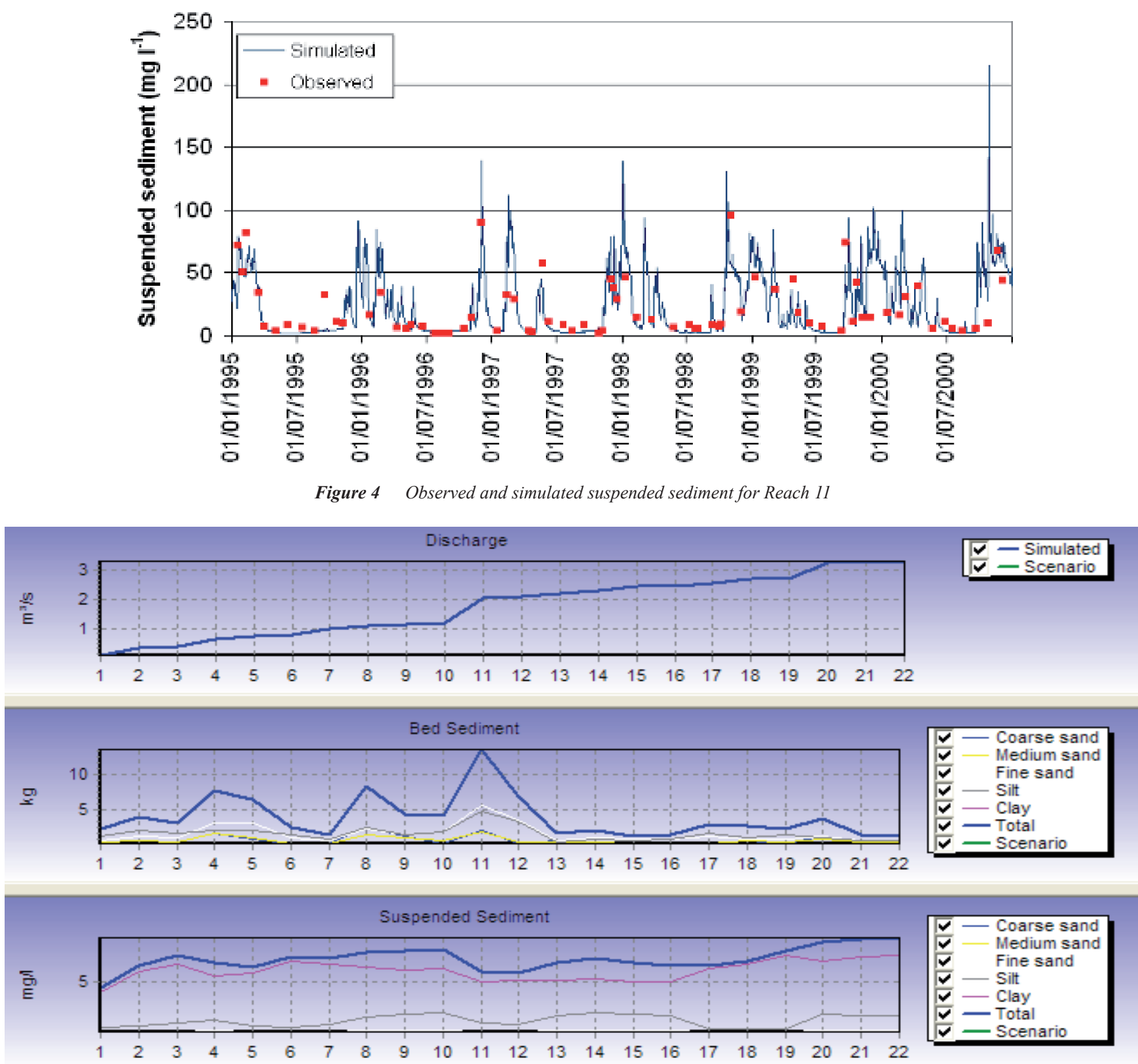

Figure 5 Profile of flow, bed and suspended sediment along the River Lugg simulated for $7^{\text {th }}$ September 2005

\section{Sediment control options and scenarios}

Five sediment management scenarios were selected to investigate potential control measures on sediments in the River Lugg. A range of parameters within the INCA SED model can be altered to change sediment release and transport and these can be adjusted to represent different management strategies. In the current analysis five management scenarios were evaluated using the model. The scenarios included removing land from agricultural production (scenario 1) and a series of best management practices (BMPs) applied either individually or in combinations, as follows:

\section{Scenario 1: Change in land use}

Two land use change scenarios were run. In Scenario 1a, 20\% less arable land was assumed, whereas in Scenario 1b, $40 \%$ less arable land was assumed. The removed land from arable land management was converted to forest and grassland.

Scenario 2: Contour tillage and planting on arable land Contour tillage (ie ploughing) and planting reduces the flow velocity, and increasing the trapping of sediment by the vegetation. According to the literature, there can be a $10-50 \%$ decrease in soil loss if contour tillage and planting is applied (Neitsch et al., 2005). The average sub-catchment slopes ranges between 3 and $12 \%$; therefore a $50 \%$ reduction in the flow erosion rate of arable land was assumed in the scenario.

\section{Scenario 3: Use of grass hedges with contour tillage on agricultural land}

Grass hedges are narrow strips of dense perennial vegetation that are planted close to land slope contours and spaced at 1-2 m vertical intervals across cropped fields. As soil is transported, sediment is removed from below the upper grass hedge and deposited upslope of next grass hedge. Therefore, the steepness of the cropped interval is reduced, which slows runoff and reduces future erosion (Dabney et al., 1999). Dabney et al. (1999) observed 35\% sediment trapping efficiency; Gilley et al. (2000) measured 53-63\% efficiency and Blanco-Canqui et al. (2004) 80\% efficiency. Therefore, to apply a conservative measurement in the scenario, the "flow erosion rate' parameter was reduced by $50 \%$.

\section{Scenario 4: Use of riparian buffer zones}

Riparian buffer zones have many advantages (Rabeni and Smale 1995). They minimise overland transport of sediment 
(reduce the direct runoff flow velocity and filter the direct runoff); stabilise channel banks (protects the banks from erosion) and trap sediment during overbank flow. In a literature review, Liu et al. (2008) suggest 45-100\% sediment removal efficiency depending on the width of the buffer zone and physical characteristics of the site. Since riparian buffer strips are currently not a legal requirement in the UK, it is assumed that there is a discontinuous buffer zone along the stream. Discontinuous buffer zones allow bank erosion and localised unfiltered diffuse sediment input. Therefore, a 15\% decrease of the transport capacity parameter of INCA-Sed is probably realistic.

Scenario 5 (3\&4): Grass hedges and riparian buffer zones Grass hedges and riparian buffer zones may have synergistic effects. Hedges will reduce in-field sediment transport and riparian buffer zones will trap sediment at the stream edge.

\section{Scenario results}

The results from the scenario analysis demonstrate significant reductions in sediment concentrations and loads. Figure 6 shows the percentage reductions achieved under each scenario and they range from $3 \%$ to $19 \%$. The most efficient single management strategy seems to be Scenario $1 \mathrm{~b}$ in which there is a $40 \%$ reduction in arable land. The other scenarios also achieve significant reductions of between $7 \%$ and $9 \%$ reduction, with the buffer strips produce the best result at close to $9 \%$. The combined strategy of 3 and 4 together (i.e. both hedges and buffer strips) produces a $14 \%$ reduction. The overall results suggest that if the hedge introduction, the contour tillage and the buffer strips were all applied, then the sediment reductions would total $24 \%$ which is a significant reduction in sediment load. A more detailed analysis of the sub-catchment data shows that the hot spots of diffuse sediment erosion are sub-catchments 4,11, 13, 18, 20. However, sediment control for the large sub-catchments 11 and 20 are by far the most important because of their size. Sediment control efforts in these two sub-catchments will have the most positive impact on the environment.

\section{Cost-effectiveness analysis}

Traditional cost effectiveness analysis (CEA) assigns monetary costs to environmental benefits (i.e. O'Shea and Wade, 2009). Monetary costs can be hard to determine in
Table $1 \quad$ Land lost from production, reduction in sediment yield and improvement relative to contour ploughing scenario for reach 21.

\begin{tabular}{llcc}
\hline Scenario & \% land lost & $\begin{array}{l}\text { Reach 21\% } \\
\text { sediment reduction }\end{array}$ & $\begin{array}{l}\text { Incremental } \\
\text { effectiveness }\end{array}$ \\
\hline 1a & 20 & 9.6 & 0.13 \\
$1 \mathrm{~b}$ & 40 & 19.7 & 0.31 \\
2 & 0 & 7.1 & 0.13 \\
3 & 1.5 & 7.3 & 1.10 \\
4 & 1.5 & 8.8 & 2.44 \\
$5(3 \& 4)$ & 3 & 14.5 & \\
\hline
\end{tabular}

an environment of widely varying fuel and fertiliser prices and volatile prices for agricultural products. However, the land footprint required for sediment reduction strategies is relatively easy to calculate. Scenario $1 \mathrm{a}$ and $\mathrm{b}$ remove 20 and $40 \%$ of the land respectively. Scenario 2, contour tillage, has at most a minimal effect on the amount of land in production. It has been suggested that at least 1 hectare of buffer strip is required to treat runoff from every 100 hectares of farmland (Association of River Trusts, 2009). Thus, buffer strips will reduce the area of productive land by at least $1-2 \%$ (average $1.5 \%$ ). We make a similar assumption for the area taken out of production by new grass hedges. Therefore, the combined land loss due to buffer strips and hedges will be between 2 and $4 \%$ (average 3\%). As scenario 2 (contour ploughing) reduces sediment yield with no loss of area the effectiveness of the other strategies was relative to it. Incremental Effectiveness is defined here as the reduction in sediment yield above and beyond that achieved with contour ploughing. Cost was defined as the land lost from production.

From Table 1, it can be seen that the most costeffective strategy was a combination of buffer strips and grass hedges $(2.4 \%$ reduction in sediment yield above that achievable with contour ploughing for a $1 \%$ loss in farmed area). A $20 \%$ retirement of agricultural land or planting of grass hedges were the least cost-effective strategies but they both provided equal benefit per unit area land lost. Riparian buffer strips are arguably the best single BMP for reducing sediment yield. While the results presented in Table 1 are probably best interpreted in a qualitative manner, it is clear that multiple BMPs can operate in a synergistic manner to produce greater improvements in environmental status than could be achieved with individual methods.

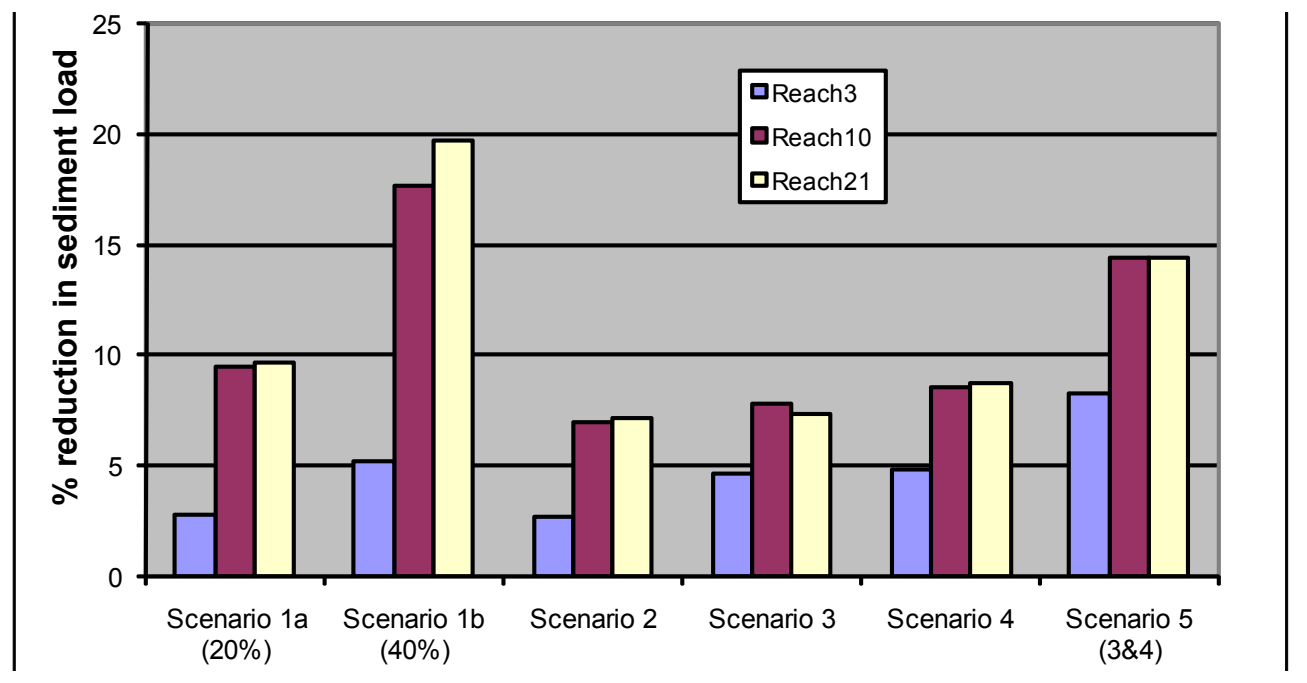

Figure 6 Percentage Reductions in Sediment Concentrations Achieved under a Range of Scenarios for Reaches 3,10 and 21 on the River Lugg. 


\section{Conclusions}

INCA-Sed has been developed as a process-based, dynamic model and has been applied to the River Lugg catchment to assess sediment control. The model does provide some interesting insights into sediment management in the Lugg catchment and suggests the combined effects of best management practices, including hedges, buffer strips and contour tillage, will significantly reduce sediment concentrations in the river, thereby assisting with efforts to improve the ecological management of the river system.

\section{References}

Armstrong, J.D., Kemp, P.S., Kennedy, G.J.A., Ladle, M. and Milner, N.J. 2003. Habitat requirements of Atlantic salmon and brown trout in rivers and streams. Fish Res, 62,143-170.

Association of River Trusts. 2009. Using vegetation to protect soils: Buffer Zones - Practical examples. Pinpoint Best Practice Information Sheet 28.0b.

Bilotta, G.S. and Brazier, R.E. 2008. Understanding the influence of suspended solids on water quality and aquatic biota. Water Res, 42,2849-2861.

Blanco-Canqui, H., Gantzer, C.J., Anderson, S.H., Alberts, E.E. and Thompson, A.L. 2004. Grass Barrier and Vegetative Filter Strip Effectiveness in Reducing Runoff, Sediment, Nitrogen, and Phosphorus Loss Soil Sci. Soc. Amer. J., 68,1670-1678.

Boorman, D.B., Hollis, J.M. and Lilly, A. 1995. Hydrology of soil types: A hydrologically based classification of the soils of the United Kingdom. Report No. 126. Institute of Hydrology, Wallingford. 146pp.

Cohen, S. and Hindmarsh A. 1996. CVODE, a Stiff/Nonstiff ODE Solver in C. Comput. Phys., 10, 38-43

Council of the European Union 2000. Water Framework Directive (2000/60/EC). Official Journal, L 327. 73pp.

Dabney, S.M., Liu, Z., Lane, M., Douglas, J., Zhu, J. and Flanagan, D.C. 1999. Landscape benching from tillage erosion between grass hedges. Soil Till. Res., 51, 219-231.

EA. 2009. Water for Life and Livelihoods, River Basin Management Plan. Severn River Basin District, Environment Agency, 64 pp.

EA .2003. River Wye Salmon Action Plan (2003 - 2008). Environment Agency, 29pp.

Gilley, J.E., Eghball, B., Kramer, L.A. and Moorman, T.B. 2000. Narrow grass hedge effects on runoff and soil loss. $J$. Soil Water Conserv., 55, 190-196.

Greig, S.M., Sear, D.A. and Carling, P.A. 2005. The impact of fine sediment accumulation on the survival of incubating salmon progeny: Implications for sediment management. Sci. Total Environ, 344, 241-258.

Jarritt, N.P. 2004. Catchment-scale sediment delivery: the development of a tool for the simulation of in-stream suspended sediment concentrations. Thesis R9636, University of Reading.

Jarritt, N.P. and Lawrence, D.S.L. 2007. Fine sediment delivery and transfer in lowland catchments: modelling suspended sediment concentrations in response to hydrological forcing. Hydrol. Process., 21, 2729-2744.

Jarvis, M.G., Allan, R.H., Fordham, S.J., Hazelden, J., Moffat, A.J. and Sturdy, R.G. 1984. Soils and their use in South East England. Soil Survey of England and Wales, Bulletin No. 15. Harpenden.

Jarvie, H.P., Jürgens, M.D., Williams, R.J., Neal, C., Davies, J.J.L., Barrett, C. and White, J. 2005. Role of river bed sediments as sources and sinks of phosphorus across two major eutrophic UK river basins: the Hampshire Avon and
Herefordshire Wye. J. Hydrol., 304, 51-74.

Lazar, A.N., Butterfield, D., Futter, M.N., Rankinen, K., Thouvenot-Korppoo, M., Jarritt, N., Lawrence, D.S.L., Wade, A.J. and Whitehead, P.G. 2010. An assessment of the fine sediment dynamics in an upland river system: INCASed modifications and implications for fisheries. Sci. Total Environ., doi:10.1016/j.scitotenv.2010.02.030.

Liu, X., Zhang, X. and Zhang, M. 2008. Major factors influencing the efficacy of vegetated buffers on sediment trapping: A review and analysis. J. Environ. Qual., 37, 1667-1674.

Neal, C., Neal, M., Leeks, G.J.L., Old, G., Hill, L. and Wickham, H. 2005. Suspended sediment and particulate phosphorus in surface waters of the upper Thames Basin, UK. J. Hydrol., 330, 142-154.

Neitsch, S.L., Arnold, J.G., Kiniry, J.R. and Williams, J.R. 2005. Soil and Water Assessment Tool Theoretical Documentation - version 2005. Temple, Texas, USA. 494pp.

O'Shea, L. and Wade, A.J. 2009. Controlling nitrate pollution: an integrated approach. Land Use Policy, 26, 799-808.

Rabeni, C.F. and Smale, M.A. 1995. Effects of siltation on stream fishes and the potential mitigating role of the buffering riparian zone. Hydrobiologia, 303, 211-219.

Scheurer, K., Alewell, C., Bänninger, D. and BurkhardtHolm, P. 2009. Climate and land-use changes affecting river sediment and brown trout in alpine countries - a review. Environ. Sci. Pollut. R., 16, 232-242.

Tetzlaff, D., Soulsby, C., Bacon,. P.J., Youngson, A.F., Gibbins, C. and Malcolm, I.A. 2007. Connectivity between landscapes and riverscapes - a unifying theme in integrating hydrology and ecology in catchment science? Hydrol. Process., 21, 1385-1389.

Wade, A.J., Butterfield, D., Griffiths, T. and Whitehead, P.G. 2007. Eutrophication control in river-systems: an application of INCA-P to the River Lugg. Hydrol. Earth Syst. Sci., 11, 584-600.

Wade, A.J., Durand, P., Beaujouan, V., Wessel, W.W., Raat, K.J., Whitehead, P.G., Butterfield, D., Rankinen, K.and Lepistö, A. 2002a. A nitrogen model for European catchments: INCA, new model structure and equations. Hydrol. Earth Syst. Sci., 6, 559-582.

Wade, A.J., Whitehead, P.G., Hornberger, G.M., Jarvie, H.P. and Flynn, N. 2002b. On modelling the impacts of phosphorus stripping at sewage works on in-stream phosphorus and macrophyte epiphyte dynamics: a case study for the River Kennet. Sci. Total Environ., 282-283, 395-415.

Walling, D.E., Collins, A.L. and Stroud, R.W. 2008. Tracing suspended sediment and particulate phosphorus sources in catchments. J. Hydrol., 350, 274-289.

Whitehead, P.G., Wilby, R.J., Battarbee, R.W., Kernan, M. and Wade, A.J. 2009. A review of the potential impacts of climate change on surface water quality. Hydrolog. Sci. J., 54, 101-124

Whitehead, P.G., Wilson, E.J. and Butterfield, D. 1998. A semi distributed Integrated Nitrogen model for multiple source assessment in Catchments (INCA): Part I - model structure and process equations. Sci. Total Environ., 210/211, 547-558. 